Structural-logical analysis of the functions of cross-curricular relations is carried out with the purpose of its application in the study of the stages of development of relations between educational subjects, in particular dialectical, logical, psychological and didactic properties of them are analyzed. On the basis of the analysis the author describes the ways of establishing cross-curricular relations, which provide the possibility of cross-cutting application of knowledge and skills acquired in the structure of different disciplines and systematization of their assimilation by students. The importance of combining the content material with the corresponding organizational and methodological activity of the participants of the educational and cognitive process is emphasized.

It is proposed to distinguish four stages of development of cross-curricular relations from information and reproductive to research and problematic, depending on the level of independence, activity and creativity of students in the process of their use. Emphasis is placed on the importance of each of the identified steps in applying cross-curricular relationships and how they are implemented at each stage.

Particular attention is paid to the research of such ways of establishing crosscurricular links as reminders, messages, concretization of educational material of related disciplines at the informational stage; repetition, comparison, application of the acquired knowledge in different types of educational and practical activity, transfer of methods of action of intersubject property at the stage of reproduction; search of independent and creative works at the research stage; cross-curricular cognitive tasks at the stage of implementation of cross-curricular communication in a problematic way.

The author foresees the prospect of further research in the testing of the presented ways of making cross-curricular relations in the educational process of the primary school system.

Key words cross-curricular relations, didactic aspect, information way of implementation, transfer of actions of cross-curricular property, search creative works, research stage, problem, primary education.

удк 796.015.58-053.5

Євгеній Проскуров

Харківська гімназія № 14

ORCID ID 0000-0002-4428-1743

Олег Камаєв

Харківська державна академія фізичної культури

ORCID ID 0000-0003-4358-888X

DOI 10.24139/2312-5993/2019.08/108-122

\title{
ОСОБЛИВОСТІ РЕГЛАМЕНТАЦІЇ СТАТИЧНИХ НАВАНТАЖЕНЬ ДЛЯ УЧНІВ СЕРЕДНЬОГО ШКІЛЬНОГО ВІКУ
}

У статті розглядається проблема регламентації статичних навантажень для спортивно-ігрового модуля шкільної програми «баскетбол», що займає десять хвилин навчального часу другої половини основної частини уроку. У ході дослідження було розраховано припустимий обсяг навчального часу в хвилинах, потрібний для використання комплексу статичних вправ в умовах шкільного уроку фізичної культури. Установлено: загальний обсяг навчального часу на статичну м'язову роботу, кількість вправ, тривалість спроб, кількість повторень у спробах, а також ї інтенсивність. Виявлено оптимальні проміжки часу для відпочинку меж спробами в секундах, послідовність регламентації навчального навантаження, якої треба 
притримуватися під час виконання спеціалізованого комплексу статичних вправ баскетболіста зі школярами середнього шкільного віку.

Ключові слова: регламентація навантажень, статичне навантаження, м'язова робота, кількість спроб, інтенсивність, обсяг навчального часу, варіанти повторень.

Постановка проблеми. Знайти оптимальну регламентацію навантажень при проведенні занять, завжди займала важливе місце в плануванні навчального процесу. Визначення сутності даної проблеми і досі має багато невирішених питань. Ураховуючи особисту придатність до фізичного виховання, кожен із методів означеної низки охоплює від 30 до 50 хвилин навчального часу, що притаманно для спортивно-секційних занять. У шкільних умовах, де стандартні норми уроку не перебільшують 45 хвилин, указані методи використовуватися не можуть. Також дані методи розраховані на дуже важке навантаження, яке не під силу звичайним учням. У зв'язку з цим для вирішення загальноосвітніх завдань потрібна інша логічна послідовність.

Аналіз актуальних досліджень. Провідні фахівці фізичного виховання мають особистій підхід до використання методичних прийомів. Зазвичай, на практиці віддається перевага одному з описаних методів, або їх різним сполученням. Зачасту вони чергуються в певно встановленій послідовності протягом одного або декількох суміжних занять. У діяльності вчителя фізичної культури, тренера зі спорту, педагога-організатора 3 фізкультурно-оздоровчої та рекреаційної роботи, окрім поняття «метод», використовується й термін «методичний прийом».

Під методичним прийомом розуміють способи реалізації того або іншого методу в конкретній педагогічній ситуації (Круцевич, 2012, с. 105). Думка іншого фахівця (Шиян, 2008, с. 140) докладніше торкається творчості шкільного вчителя. Методи - це способи взаємної діяльності учня і вчителя, спрямованої на вирішення навчально-виховних завдань. Методичні прийоми - це шляхи реалізації методів у конкретних випадках і умовах процесу фізичного виховання. Педагог повинен досконало володіти всіма методами фізичного виховання. Діапазон застосування методу залежить від запасу методичних прийомів. Творчістю вчителів створюються щораз нові прийоми, тому їх багато, і вони не підлягають суворому обліку. Обсяг методичних прийомів, які знаходяться в арсеналі вчителя, значною мірою визначає його професіоналізм та ефективність викладання.

Переважно інший погляд автора (Арефьєв, 2015, с. 7) свідчить, що у процесі фізичного виховання необхідно не тільки методично правильно здійснювати кожну локальну програму (розвиток сили, швидкості, витривалості тощо), а й зберігати правильне співвідношення між величиною дії кожної програми, що йде паралельно (співвідношення фізичних вправ різної спрямованості у програмах розвивально-оздоровчих занять). Більше того, така вимога особливо має бути застосована при розробці відповідних програм для підлітків із урахуванням їхнього біологічного віку. Дослідження 
іншого автора (Аксьонова, 2014, с. 18) щодо сучасного фізичного навантаження дозволило встановити, що традиційна структура заняття фізичною культурою в ЗДО і уроку фізичної культури у $33 С 0$ не створює умов щодо виконання вимог регулювання фізичного навантаження, зазначених у державних нормативних документах, наявність «фізіологічної ями» на початку уроку, пилкоподібна форма фізіологічної кривої свідчать про відсутність фітнес-зони, під час якої має відбуватися кардіотренування. У проаналізованих літературних джерелах наступний автор (Рябченко, 2017, c. 422) рекомендує комплексно розглянути структуру і зміст занять, представити чіткі умови навчання, визначити їх послідовність.

Однак, найбільш виразною характеристикою регламентації навантажень $€$ формулювання (Курамшин, 2010, с. 56), де автор загострює, що в основі методів, спрямованих на вдосконалення рухових навичок і розвиток фізичних здібностей, лежить певний спосіб поєднання й регулювання навантаження в процесі відтворення вправи або той чи інший засіб упорядкування дій учнів і умов їх виконання. Таким чином, на основі аналізу поглядів провідних фахівців можливо стверджувати, що при безперервному варіюванні застосовуваними навантаженнями складаються умови, згідно 3 якими зменшується можливість появи перевтомлення, активізуються відновні процеси в організмі, які підсилюють адаптаційні перебудови функцій і структур, що лежать в основі розвитку відповідних здібностей.

Мета дослідження - визначити оптимальне навантаження спеціалізованого комплексу статичних вправ баскетболіста для школярів середнього шкільного віку.

Методи дослідження. Метод узагальненого порівняння даних літературних джерел, метод планувань навчальних навантажень, метод розрахунку ефективного часу для навчальних навантажень, метод педагогічного спостереження. Серед групи практичних методів, які використовують у фізичному вихованні для опанування фізичних вправ, $\epsilon$ методи навчання в цілому і по частинам. Однак, регламентація навантажень залежить від специфіки вправ, їх спрямованості, віку учнів, їх рівня фізично стану, фізичної підготовленості. У даному випадку було розроблено регламентацію статичних вправ, що виконуються учнями початку середнього шкільного віку, цілісним методом.

\section{Задачі дослідження:}

1. Розрахувати припустимий обсяг навчального часу в хвилинах під час виконання комплексу статичних вправ в умовах шкільного уроку фізичної культури.

2. Установити загальний обсяг навчального часу на статичну м'язову роботу, кількість вправ, тривалість спроб, кількість повторень у спробах та інтенсивність навантаження. 
3. Із припустимого обсягу навчального часу обрати ефективні проміжки для відпочинку в секундах.

Виклад основного матеріалу. У нашому дослідженні регламентація статичного навантаження для ігрового модуля шкільної програми «баскетбол» розглядається як одна з частин його загальної та спеціальної складової фізичного навантаження на уроці, де статичні вправи, знаходячись у спільному контексті всього обсягу навчального матеріалу, не просто доповнюють його зміст, а надають певну орієнтацію для вирішення освітньої, виховної, оздоровчої та розвивальної спрямованості навчального процесу незалежно від мети і завдань заняття.

Таким чином, головне місце серед низки методів удосконалення рухових навичок і розвитку фізичних якостей у даному навантаженні займає метод його регламентації (рис. 1). Особливість статичних вправ обумовлюється їх специфікою, яка належить до частки таких спеціальних рухів, що потрібні учням для профілактики травматизму, набуття спеціалізованих навичок, а також являють необхідність удосконалення деяких головних динамічних рухів вже в якості допоміжних вправ.

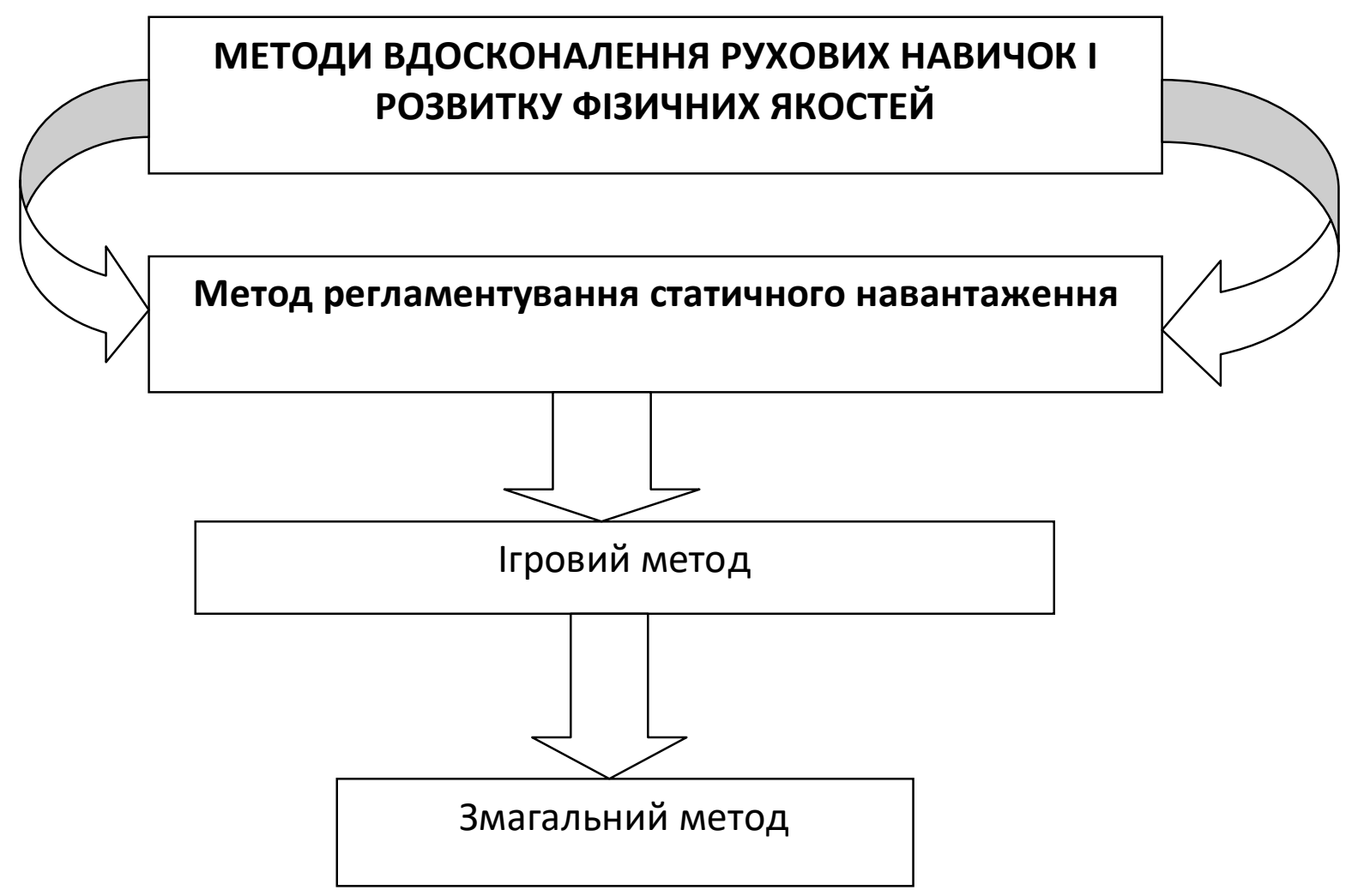

Рис. 1. Група практичних методів

ще однією відліковою рисою даних навантажень $€$ те, що вони надають можливість учням легко регулювати ступінь інтенсивності тренувального впливу в залежності від власного стану, або в залежності від того, наскільки вони можуть виконати дану рухову дію без витрат особливих зусиль свого здоров'я. Так склалося, що в силових, швидкісно-силових і швидкісних вправах максимально можлива індивідуальна інтенсивність приймається як 
початкова (100 \% - максимальна інтенсивність), по відношенню до якої встановлюють окремі ступеня інтенсивності. Наприклад, силова робота статичного характеру з величиною напруги до 15 \% максимальної статичної сили в цій вправі забезпечується виключно за рахунок аеробних джерел енергії (Круцевич, 2012, с. 90).

Як підтвердження сказаному, спеціальні дослідження (Камаєв, 2013, с. 120) дозволили встановити, що статичне навантаження з власною масою тіла не супроводжується великими і тривалими зусиллями. У зв'язку з цим реакція серцево-судинної системи на це навантаження менш виражена й більш адекватна дітям 10-11 років. Отже, дане навантаження функціонально є менш напруженим для шкільного віку й його можливо рекомендувати при проведенні занять із фізичної культури.

Але 3 початку було потрібно розрахувати припустимий обсяг навчального часу, який би задовольнив застосування комплексу статичних вправ в умовах шкільного уроку фізичної культури. За вимогами чинної програми фізичного виховання головними складовими основної частини уроку даного модуля $\epsilon:$ спеціальна фізична підготовка і тактико-тактична підготовка, які за своїм змістом складаються з динамічних вправ, але їх послідовність може змінюватися від різноманітних чинників, до яких належать: ціль та мета заняття, готовність учнів виконувати фізичні вправи, стан матеріально-технічної бази. Термін основної частини загальноосвітнього уроку з фізичної культури для школярів триває 25 хвилин, за цей час іде навчання технічним прийомам із баскетболу, де на кожному уроці використовуються вправи загальної та спеціальної фізичної підготовки, а також іде послідовний розбір і вдосконалення пройденого матеріалу.

Однак, ми обрали першою тактико-тактичну підготовку, оскільки вона охоплює дотримання методики послідовного навчання атакуючим i захисним діям з прийомами техніки гри, де також широко використовуються підвідні вправи, безпосередньо залучаючи рухи ігрового характеру, а спеціальну фізичну підготовку залишили наступною, оскільки після неї, тобто наприкінці основної частини учні виконували вже комплекси статичних вправ спеціалізованої спрямованості, які мають відношення для модуля «баскетбол».

Такий вигляд мала загальна схема основної частини уроку, що відповідала умова послідовності навчання, де з початку йшли динамічні вправи, а статичні залишалися наприкінці. Це було зроблено з метою кращої послідовності заняття, яка суттєво впливає на біохімічні, морфологічні та фізіологічні процеси в організмі, забезпечуючи умови для його якісного розвитку (рис. 2).

Водночас за ретельним розрахунком термінів послідовності кожної зі складових основної частини уроку в хвилинах було визначено, що тактикотактична підготовка і спеціальна фізична підготовка займають по 7,5 хвилин, 
тим самим загальна сума в хвилинах терміну, відведеного на динамічні вправи, тривала 15 хвилин, а останні 10 хвилин займали спеціалізовані статичні вправи для модуля «баскетбол». У такому вигляді було отримано припустимий обсяг навчального часу в хвилинах для комплексу статичних вправ в умовах шкільного уроку фізичної культури. Дана регламентація 3 успіхом забезпечила зручне використання інших методів низки «вдосконалення рухових навичок і розвитку фізичних якостей».

\section{ЗМІСТ НАВЧАЛЬНОГО МАТЕРІАЛУ МОДУЛЯ «БАСКЕТБОЛ»}
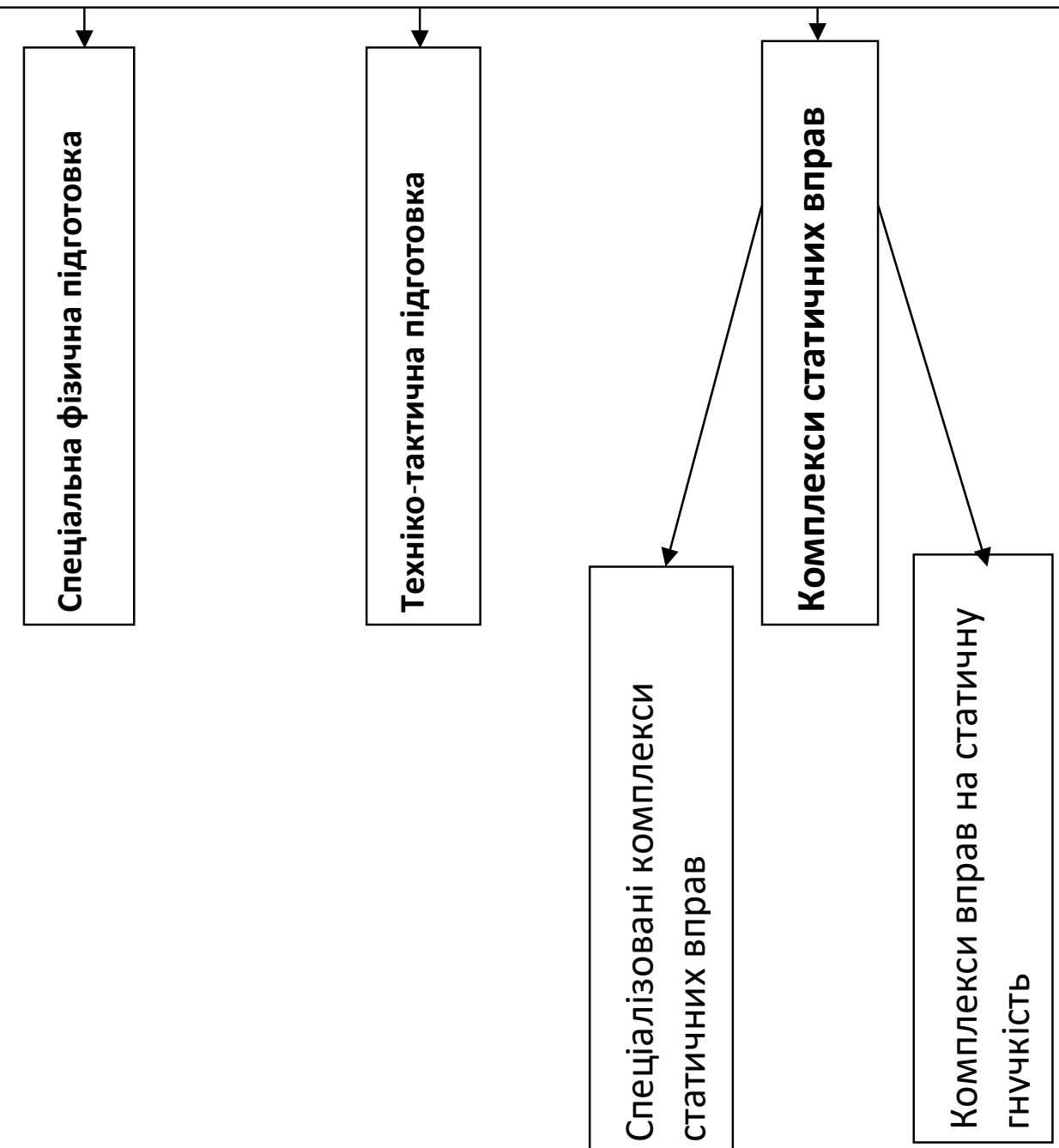

Рис. 2. Структурно-логічна схема календарного плану занять по модулю «баскетбол»

Так, наприклад, на шкільному занятті йде вдосконалення й закріплення придбаних раніше статичних умінь та навичок під час навантаження вказаних груп м'язів, але за індивідуально зручними для кожного учня статичними вправами. Школярі пересуваються по колу легким бігом, але за командою вчителя зупиняються на місці, або швидко 
знаходять потрібного приладу й виконують статичну вправу, потім за іншою командою повертаються до кола та продовжують легкий біг.

У даному випадку для покращення придбаних навичок легко застосовується зручний ігровий метод. Інша ситуація, з учнями напередодні обговорюється майбутній план дій. Обираються добре знайомі статичні вправи, які учні повинні виконати на оцінку. Також обговорюються помилки і час утримання статичних поз. Клас розподіляється на дві групи, одна група виконує вправи, інша - бере на себе обов'язки суддів, далі відбувається зміна функцій учнів, ті, які судили, виконують вправи, а ті, які виконували вправи, виступають у ролі суддів. У даному випадку легко використовується змагальний метод.

Надалі перед нами стояло завдання встановити: загальний обсяг навчального часу на статичну м'язову роботу, загальний обсяг часу на відпочинок, кількість вправ, тривалість спроб, кількість повторень у спробах та їх інтенсивність (рис. 3). Загальний обсяг навчального часу, відведеного на статично-м'язову роботу, або на виконання статичного навантаження, складається з таких складових, до яких мають відношення: час на утримання статичного положення, загальна кількості вправ і кількість повторень у спробах. За думкою провідних фахівців, оптимальна тривалість одноразового статичного напруження повинна тривати 4-10 с. Зрозуміло, що чим вище напруження й нижчий рівень тренованості, тим воно повинно бути менш тривалим і навпаки (Шиян, 2008; Круцевич, 2012).

Початковий рівень розвитку статичної сили наших учнів довів, що оптимальна тривалість статичного положення для них складає 6 с, а загальна кількість статичних вправ у спеціалізованому комплексі, відповідно до їх тренованості, дорівнює шести, які охоплюють потрібні групи м'язів для гри в баскетбол відповідно віку. Стосовно цього, планування дозувань навчальних навантажень схилялося спочатку до врахування думки провідних фахівців фізичного виховання, які радять в одному підході виконувати від 2-3 до 56 повторень (Шиян, 2008; Круцевич, 2012), відповідно до неї нами було втілено на практиці оптимально середню кількість повторень від 3 до 4, що $є$ в межах дозволеного. Виходячи з цього, загальний обсяг навчального часу на статично м'язову роботу складають три вправи по шість секунд, які повторюються три рази, а також три вправи по шість секунд, які повторюються чотири рази.

Арифметично це можливо виразити таким чином: $(6 c \times 3 в \times 3 p)+(6 c \times 3 в \times 4 p)=126$ c, де отриманий результат у секундах дорівнює 2 хв 10 с. Таким чином, було встановлено, що загальний обсяг навчального часу на статично м'язову роботу займає дві хвилини і десять секунд, що дорівнює $20 \%$ від загального часу, відведеного на весь комплекс статичного навантаження, який займає 10 хвилин, тоді на час 
відпочинку й відновлення після статичного напруження залишається 8 хвилин, що складає 80 \% від загального часу, відведеного на комплекс.

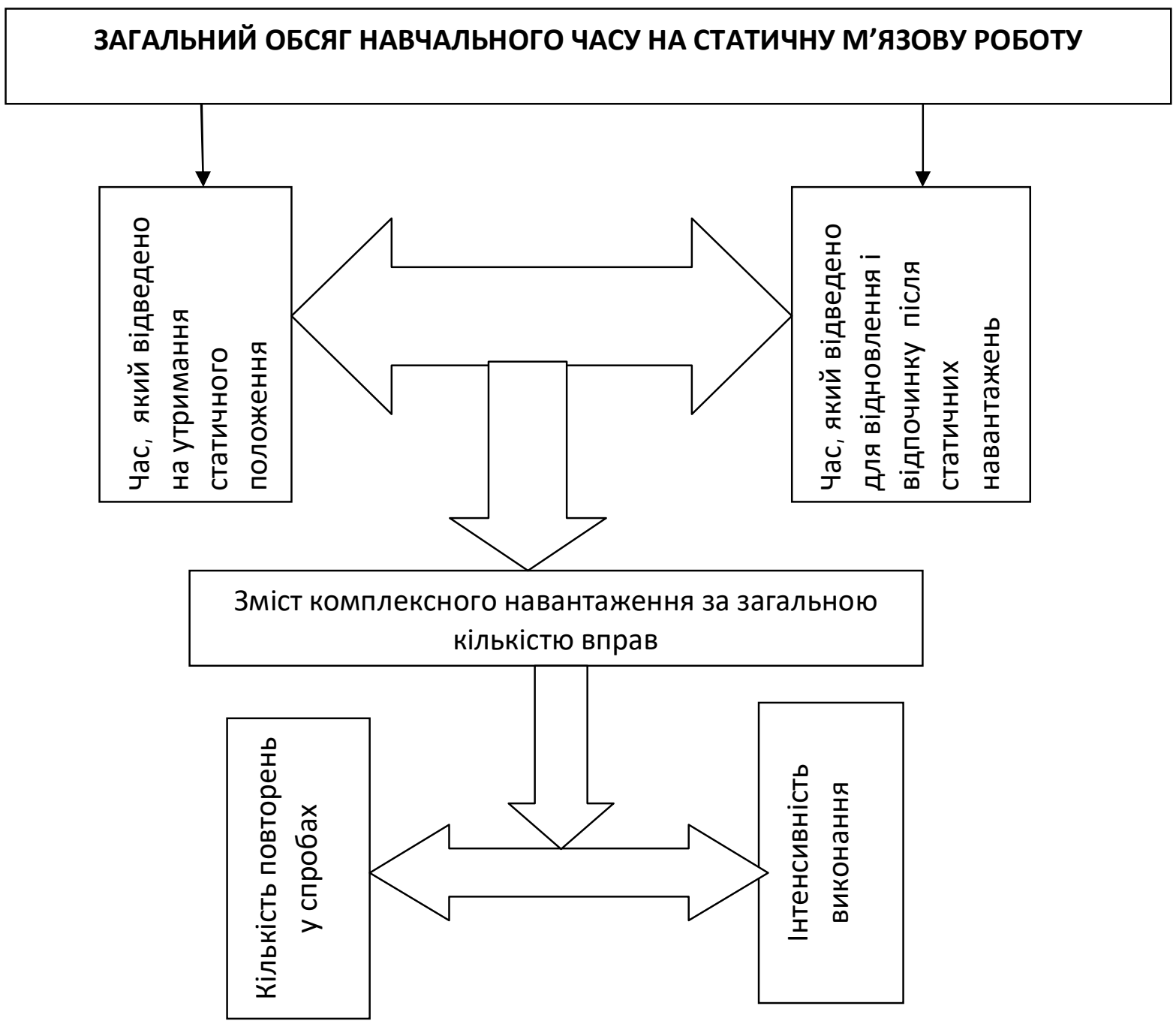

Рис. 3. Структурно-логічна схема спеціалізованих комплексів статичного навантаження для ігрового модуля «баскетбол»

Це безпосередньо було зроблено з метою поліпшення умов при використанні фронтального способу (метода) організації учнів на занятті, який $\epsilon$ найбільш ефективним у даному випадку, що водночас сприяє усуненню недоліків та проведенню освітніх і виховних функцій, оскільки за період великого відпочинку відбувається не тільки адаптація учнів для майбутнього повторення вправи, але також школярі слухають зауваження вчителя з приводу своїх помилок, одержуючи рекомендаційні вказівки до їх виправлення і цей мотив налаштовує на позитивний настрій, підбадьорює на працю, забезпечує активну участь усіх учнів.

Взагалі, коли в першій половині основної частини уроку йдуть динамічні вправи, а завершують другу частину статичні, то такий підхід урізноманітнює заняття і $є$ перспективним не тільки для розвитку життєво 
необхідних фізичних якостей, удосконалення рухового досвіду, надання більшої рухової активності, а також досягає вдало спланованої організації учнів. Але, слід зазначити, що комплекс статичних навантажень, як уже було зазначено на рис. 2, має два різновиди, які повинні одночасно використовуватися в навчанні, це комплекс статично-м'язової роботи і комплекс на статичну гнучкість. За головною сутністю основних параметрів, до яких належать: загальний обсяг навчального часу на виконання вправ статичної гнучкості, загальний обсяг часу на відпочинок, кількість вправ, тривалість спроб, кількість повторень у спробах і їх інтенсивність, даний комплекс мало чим відрізняється від статично-м'язового, але має свої відлікові риси.

По-перше, даний комплекс раніше ніколи не використовувався 3 учнями загальноосвітніх шкіл, розумілось так, що всі динамічні вправи несуть у собі необхідну частку активної гнучкості, а втручання пасивних актів статичної гнучкості $€$ болісним і може привести до негативних наслідків. Однак, на практиці провідні фахівці радять ії використання, оскільки недостатній розвиток гнучкості обмежує можливості вдосконалення інших фізичних якостей, призводить до зниження сили й швидкості, зростання втоми (Шиян, 2008, с. 227), так само, як недостатній рівень розвитку гнучкості негативно впливає на результати занять фізичними вправами_(Круцевич, 2012, с. 247).

По-друге, до змісту комплексного навантаження на статичну гнучкість було обрано три частини, до них надійшли: вправи для плечових суглобів, тулуба і тазостегнових суглобів. Слід загострити увагу, що дані вправи є фундаментальними, мають відношення до любої фізичної роботи, можуть використовуватися як перед ії початком, так і наприкінці. Але в нашому випадку комплекси вправ на статичну гнучкість у навчальній практиці виконувались як один к двом, тобто два навчальних дні поспіль було задіяна на статично-м'язові навантаження, а на третій день підходила черга комплексу на статичну гнучкість, який був спрямований на розвиток гнучкості засобами статичних вправ.

По суті, дані комплекси $€$ найбільш насиченими, оскільки вони виконуються на п'яти робочих місцях: підлога, низька перекладина, звичайна стіна, гімнастична лава, гімнастична стінка, а там, де навчальна спроможність матеріальної бази дозволяє одночасне проведення занять двом класам разом, то означені комплекси можуть охоплювати всіх учнів, забезпечуючи кожному розвивальну, оздоровчу й освітню спрямованість, але, безумовно, для цього повинна бути розроблена відповідна регламентація (рис. 4).

Водночас, їх створено для того, щоб добре підготувати учнів до нормативних іспитів на гнучкість чинної програми фізичного виховання, а також надати індивідуальну допомогу під час опанування інших модулів шкільної програми, де потрібна дана якість. Тому послідовність вправ 
сплановано таким чином, що спочатку йде основна вправа, а потім коригувальна, яка теж має своє навчально-тренувальне значення.

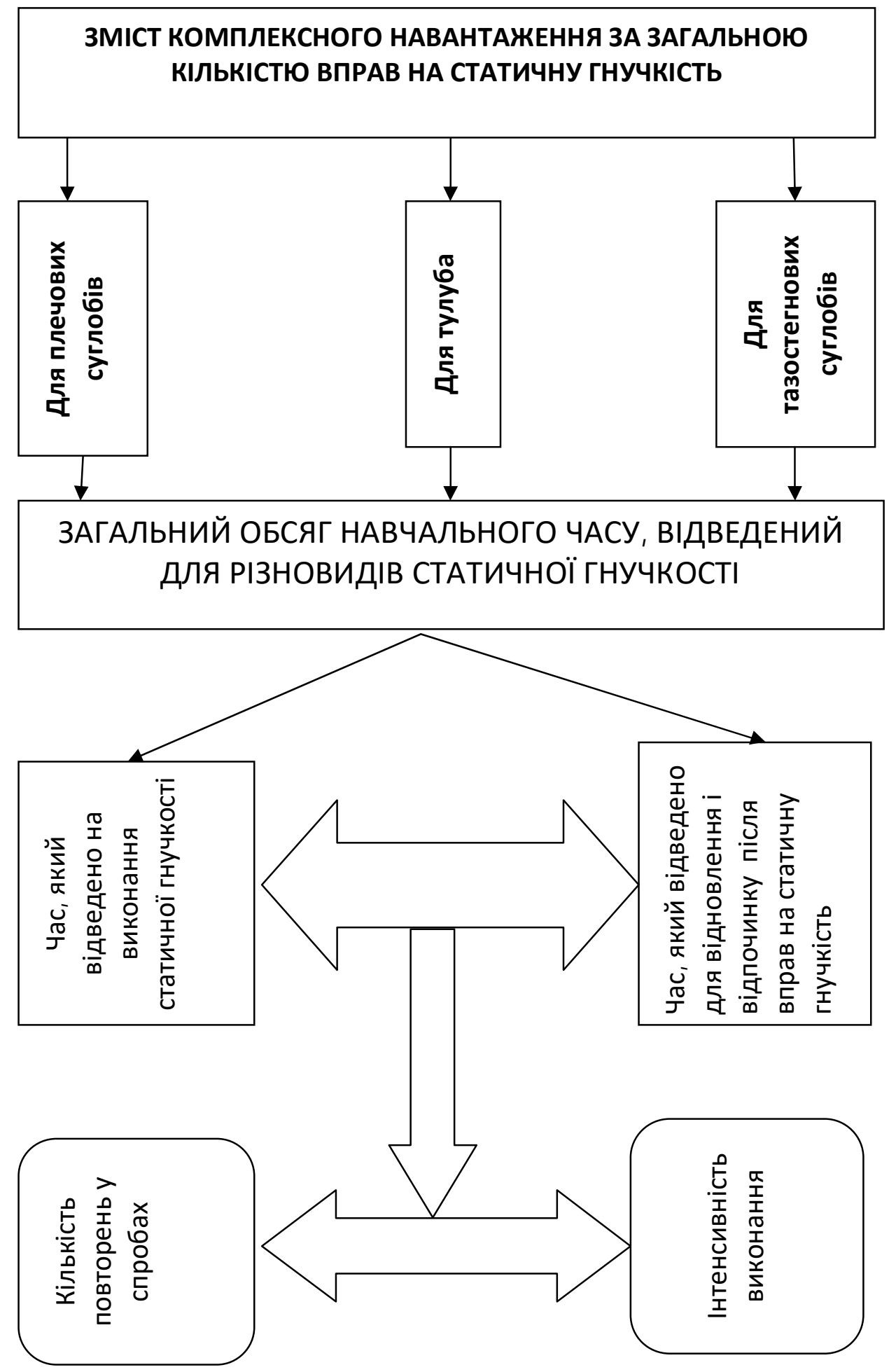

Рис. 4. Структурно - логічна схема вправ на статичну гнучкість

Одним із останніх пунктів структурно-логічних схем в обидва навантаження: статично-м'язовому і статичної гнучкості залишається їх інтенсивність. На думку провідних фахівців (Шиян, 2008; Круцевич, 2012), інтенсивність статично-м'язових вправ у першій половині напруження (2- 
4 с) зусилля повинно плавно зростати до запланованого, а потім утримуватися на цьому рівні до кінця вправи. У нашому випадку за час виконання статичних вправ (6 с) повністю виконувалися дані вимоги.

Що стосується статичної гнучкості, то за твердженням (Круцевич, 2012, с. 258), великий тренувальний ефект дає ступінчаста інтенсивність розтягування: плавно досягти близько граничної амплітуди, утримати 510 с, ланки тіла в певному положенні, а потім збільшити амплітуду на 8$12 \%$ і знову 5-10 с утримати ланки тіла в цьому положенні. Оскільки тривалість виконання вправ у наших комплексах, як було сказано раніше, має термін (6 с), то ступінчаста інтенсивність із учнями 10-11 років не застосовувалася, їм достатньо було першого ступеня, але збільшити амплітуду на 8-12 \% у наших комплексах ми радимо вже з учнями 1213 років, коли загальний термін тривалості вправи почне зростати.

Третє, останнє завдання в нашому дослідженні, де з припустимого обсягу навчального часу, обиралися зручні проміжки для відпочинку в секундах, довело, що дана регламентація нараховує шість різноманітних варіантів (рис. 5). Дані варіанти повторень не схожі один на одного, оскільки в кожному з них $є$ присутньою тільки своя певна комбінація кількості спроб, яка складається з трьох і чотирьох повторень вправи.

Нагадуємо, що вказану кількість повторень радять використовувати провідні фахівці фізичного виховання, на думку (Круцевич, 2012, с. 192) менше 3-4 повторень в одному підході в подоланні помірних обтяжень практично не стимулюють адаптаційні процеси, а більше 5-6 повторень призводять до погіршення координації роботи м'язів унаслідок накопичення стомленості. 


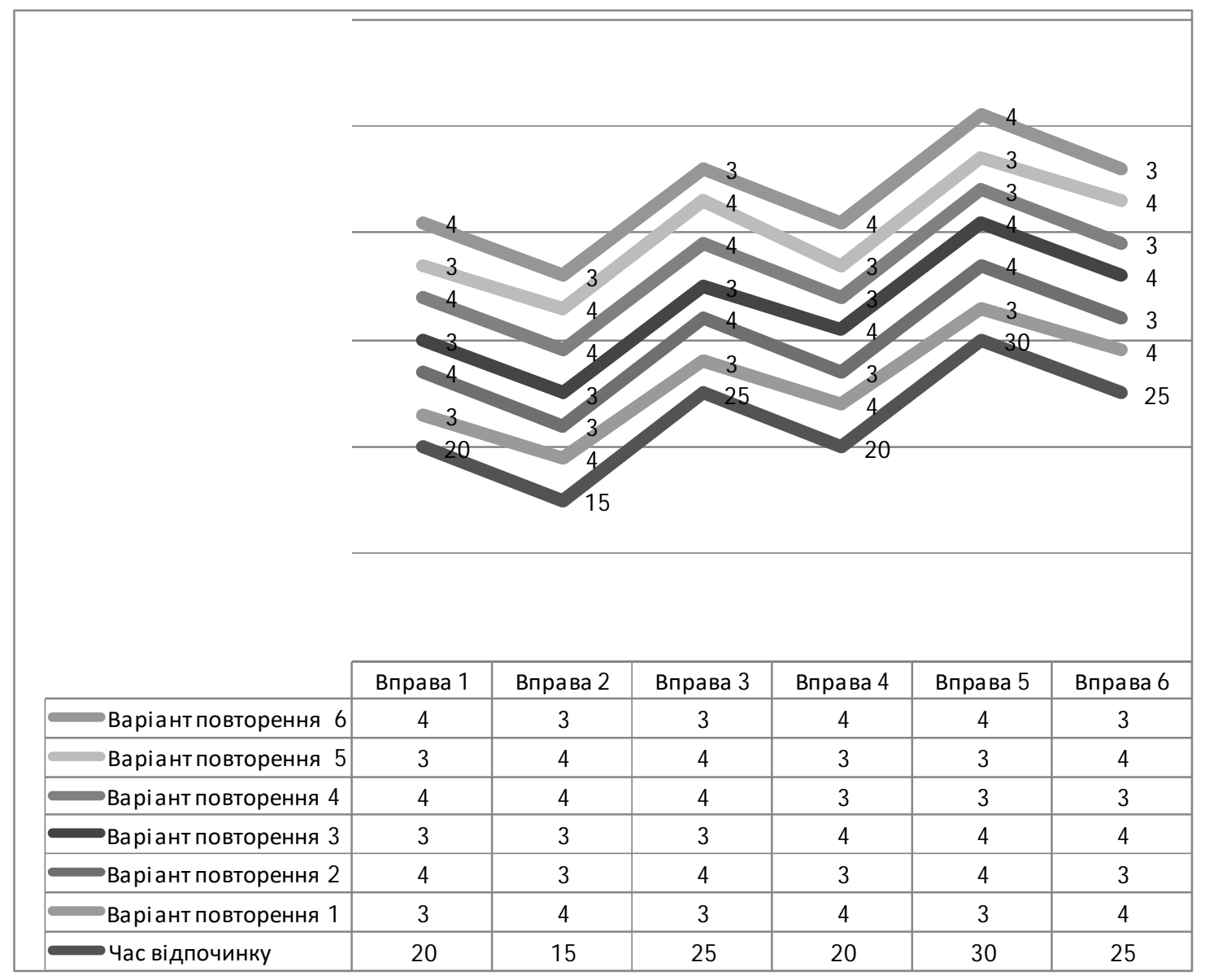

Рис. 5. Регламентація ефективного навантаження

Тому перший варіант ми почали з меншої кількості повторень і закінчили більшою, відповідно, другий починає з більшої, а закінчує меншою, де кожні наступні вправи чергуються на більшу - меншу кількість повторень у спробі, або навпаки (рис. 5). Указані варіанти ми радимо застосовувати на початку вивчення модуля протягом перших п'яти занять.

Наступні два варіанта відрізняються своєю послідовністю, де перші три вправи мають три або чотири повторення, а наступні змінюються в бік підвищення або зниження, оскільки там, де було три повторення, стає чотири, а там, де було чотири - стає три (рис. 5). Дані варіанти ми радимо використовувати, починаючи з шостого, або сьомого заняття по десяте-дванадцяте включно, залежно від адаптації учнів до статичних навантажень. Два заключних варіанти п'ятий і шостий є найскладнішими, оскільки непередбачена зміна між комбінованими повтореннями робить їх відмінними від попередніх варіантів. Вони використовуються для вдосконалення й самовдосконалення наприкінці навчального модуля, починаючи з тринадцятогочотирнадцятого занять. Звертаючи увагу на час відпочинку в кожній вправі, 
ми можемо побачити, що його зниження проходе на п'ять секунд, а підвищення на десять. Сам діапазон відпочинку в секундах складається від 20 до 30 секунд за весь загальний час виконання вправ, але в кожній вправі час відпочинку меж спробами $є$ постійним. Так, у першій вправі незалежно від кількості повторень час відпочинку між спробами триватиме 20 с, найвищої позначки він досягає на п'ятій спробі, а найнижчої - на другій (рис. 5).

Незважаючи на те, що на останній шостій вправі час відпочинку трохи знижується в порівнянні з попередньою, однак загальний час відпочинку наприкінці комплексного навантаження зростає. Це було зроблено 3 метою зручного збільшення навантажень у наступних роках середнього шкільного віку за рахунок поступового зменшення часу відпочинку залежно від готовності учнів.

\section{Висновки та перспективи подальших наукових розвідок.}

1. Під час виконання спеціалізованих статичних вправ для модуля «баскетбол» зі школярами середнього шкільного віку слід притримуватися такої регламентації: 1) час утримання нерухомого статичного положення не повинен перебільшувати тривалості зусилля 6 с; 2) кількість підібраних вправ не повинна перевищувати шести; 3) кількість повторень вправ коливатиметься в межах 3-4 разів; 4)час відпочинку між спробами повинен складати термін від 15 до 30 с; 5) залежно від напруги м'язів застосовувати діафрагмальне, або грудне дихання.

2. Загальна кількість відведеного часу для виконання спеціалізованих статичних вправ повинна тривати 10 хвилин, де 2 хвилини 10 секунд, тобто 20 \% відводиться на статичну м'язову роботу, інтенсивність якої повинна знаходитися в межах $30 \%$ від максимального свого досягнення в цієї вправі, що цілком залежить від стану самопочуття учнів.

3. Загальна кількість відведеного часу для відпочинку значно перебільшує статичну м'язову роботу і триває 7 хвилин 50 секунд, що складає 80 \% відведеного часу. Допускається будь-яка комбінація в проміжки часу від 15 до 30 секунд із індивідуальним зниженням у 5 секунд, а підвищенням у 10 секунд.

Перспективним напрямом подальших наукових розвідок може бути вивчення прояву несприятливих чинників, які стають на заваді якісному фізичному навантаженню школярів.

\section{ЛІТЕРАТУРА}

Арефьєв, В. Г. (2015). Адаптаційні передумови диференціації розвивально-оздоровчих занять з фізичної культури. Науковий часопис НПУ імені М.П. Драгоманова, Серія 15. Науково-педагогічні проблеми фізичної культури (фрізична культура $i$ спорт), Вип. 1 (54), 4-7 (Arefiev, V. H. (2015) Adaptation prerequisites for differentiation of developmental-recreational training in physical culture. Scientific journal of NPU named after M.P. Drahomanov, Series 15. Scientific and pedagogical problems of physical culture (physical culture and sport), Issue 1 (54), 4-7). 
Аксьонова, О. П. (2014). Фізіологічна крива реакції серцево-судинної системи організму дітей і підлітків на фізичні навантаження під час занять фізичною культурою. Науковий часопис НПу імені М.П. Драгоманова, Вип. Зк (44), 13-18 (Aksenova, O. P. (2014). Physiological curve of the cardiovascular system response of children and adolescents to physical activity during physical training. Scientific journal of NPU named after M.P. Drahomanov, Issue 3k (44), 13-18).

Круцевич, Т. Ю. (2012). Теорія і методика фізичного виховання. К.: Олімпійська simepamypa (Krutsevich, T. Y. (2012). Theory and M ethods of Physical Education. K.: Olympic Literature).

Курамшин, Ю. Ф. (2010). Теория и методика физической культуры. М.: Советский спорт (Kuramshin, Yu. F. (2010). Theory and methodology of physical education. M.: Soviet sport).

Камаев, О. И., Проскуров, Е. М. (2013). Особенности влияния статических и динамических нагрузок на деятельность сердечно-сосудистой системы у мальчиков 10-11 лет. Слобожанський науково-спортивний вісник, 5 (38), 117122 (Kamaiev, O. I., Proskurov, E. M. (2013). Features of the influence of static and dynamic loads on the activity of the cardiovascular system in boys 10-11 years old. Slobozhansky scientific-sports bulletin, 5 (38), 117-122.

Рябченко, Р. В. (2017). Умови ефективного керування здоров'ям школярів у процесі занять фізичними вправами. Науковий часопис НПУ імені М.П. Драгоманова, вип. 3к (84), 419-422 (Riabchenko, R. V. (2017). Conditions for the effective management of the health of schoolchildren in the process of exercise. Scientific journal of NPU named after M. P. Drahomanov, Issue 3k (84), 419-422.

\section{PEЗЮME}

Проскуров Евгений, Камаев Олег. Особенности регламентации статических нагрузок для учащихся среднего школьного возраста.

В статье рассматривается проблема регламентации статических нагрузок для спортивно-игрового модуля школьной программы «баскетбол», которая занимает десять минут учебного времени во второй половине основной части урока. $В$ ходе исследования был рассчитан допустимый объем учебного времени в минутах, необходимый для использования комплекса статических упражнений в условиях школьного урока физической культуры. Установлено: общий объем учебного времени на статично-мышечную работу, количество упражнений, продолжительность попыток, количество повторений в попытках, а также их интенсивность. Выявлены оптимальные промежутки времени для отдыха между попытками в секундах, последовательность регламентации учебной нагрузки, которой нужно придерживаться при выполнении специализированного комплекса статических упражнений баскетболиста со школьниками среднего школьного возраста.

Ключевые слова: регламентация нагрузок, статическая нагрузка, мышечная работа, количество попыток, интенсивность, объем учебного времени, варианты повторений.

\section{SUM MARY}

Proskurov Eugene, Kamayev Oleg. Features of static load regulation for middle school pupils.

The article deals with the problem of regulation of static loads for the sports-game module of the school basketball program, which takes ten minutes of study time in the second 
half of the main part of the lesson. Therefore, the purpose of this study was to determine the optimal load of a specialized set of static exercises of basketball for middle school students. The group of methods involved in the research movement was headed by the following: the method of generalized comparison of data from literary sources, the method of planning training loads, the method of calculating the effective time for training loads, the method of pedagogical observation. Among the group of practical methods used in physical education for mastering physical exercises are the methods of teaching in general and in parts. However, the regulation of the load depends on the specifics of the exercises, their focus, the age of the students, their level of physical condition, physical fitness. In this case, the regulation of static exercises performed by students of the beginning of secondary school age, a holistic method, was developed. The objectives of the study were: 1. Calculate the allowable amount of study time, in minutes when performing a set of static exercises in the conditions of school physical education lesson. 2. Determine: total amount of training time for static muscle work, number of exercises, duration of attempts, number of repetitions in attempts, and intensity of loading. 3. From the acceptable amount of study time, choose effective intervals for rest in seconds. During the study, the allowable amount of study time was calculated, in minutes, to use the set of static exercises in the school physical education lesson. The total amount of training time for static muscle work, the number of exercises, the duration of attempts, the number of repetitions in the attempts, as well as their intensity, which should be within $30 \%$ of their maximum achievement in this exercise, which depends entirely on the state of students' health are determined. The optimal intervals for resting the limits of the attempts in seconds have been revealed, the sequence of the regulation of the training load, which should be observed when performing a specialized set of static exercises of a basketball player with secondary school students. A promising direction for further scientific exploration may be the study of the manifestation of unfavorable factors that hinder the quality of physical activity of students. A promising direction for further scientific exploration may be the study of the manifestation of unfavorable factors that hinder the quality of physical activity of students.

Key words load regulation, static load, muscular work, number of attempts, intensity, amount of study time, repetition options. 